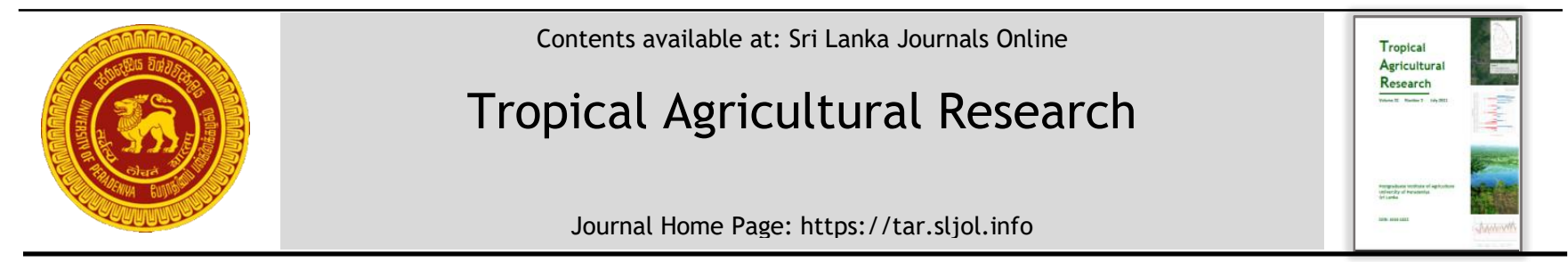

\title{
Application of Standard Precipitation Index (SPI) to Assess Rainfall variability in a Major Agricultural Area in Dry Zone of Sri Lanka
}

\author{
E.M.G.P. Hemachandra ${ }^{1 *}$, N.D.K. Dayawansa ${ }^{2}$ and R.P. De Silva ${ }^{2}$ \\ ${ }_{1}$ Postgraduate Institute of Agriculture, University of Peradeniya, Sri Lanka. \\ 2 Department of Agricultural Engineering, Faculty of Agriculture, University of Peradeniya, Sri Lanka.
}

\section{ARTICLE INFO}

\section{Article history:}

Received: 13 August 2020

Revised version received: 16 December 2020

Accepted: 19 January 2021

Available online: 30 July 2021

\section{Keywords:}

Mann Kendal Trend Test

Sen's Slope Estimator

Standard Precipitation Index

Village Tank Cascade Systems

\section{Citation:}

Hemachandra, E.M.G.P., Dayawansa, N. D.K. and De Silva R.P. (2021). Application of Standard Precipitation Index (SPI) to assess rainfall variability in a major agricultural area in Dry Zone of Sri Lanka. Tropical Agricultural Research, 32(3): 276-286.

DOI: http://doi.org/10.4038/tar.v32i3.8491

Hemachandra, E.M.G.P.

https://orcid.org/0000-0001-9744-5089

\section{ABSTRACT}

Agriculture in the dry zone of Sri Lanka is highly constrained by the inadequacy of irrigation water. The small village tanks located in these areas help farmers to cultivate their lands during dry periods by storing rainwater. However, the rainfall variability has made a considerable threat to functioning of these tanks and in providing expected benefits to the farmers. The objective of this study was to assess the climatic variability using 30-year (1989 to 2018) daily rainfall data from six rain gauging locations (Anuradhapura, Mahagalkadawala, Hingurakgoda, MahaIlluppallama, Girithale and Diyabeduma) in a small tank dominated area in the Dry Zone. Standard Precipitation Index (SPI) was calculated to assess the temporal variability of dry and wet extremes. Mann Kendal Trend Test (MK test) was used to analyze the trend of SPI and Sen's Slope Estimator to assess the magnitude of the trend. The results of Anuradhapura, Diyabeduma and Mahagalkadawala show significantly increasing trend of SPI 12/ annual rainfall. According to the SPI, there were increasing trends in First Inter Monsoon in Anuradhapura and Mahallluppallama, which have resulted an increasing rainfall trend in Yala season. Additionally, there was an increasing trend in Second Inter-Monsoon in Anuradhapura. These changes highlight that there are extreme rainfall events occurring in some seasons without making a significant impact in the annual rainfall pattern of the area.

\footnotetext{
*Corresponding author: gimhanipaboda@gmail.com
} 


\section{INTRODUCTION}

Water is a main constraint for agriculture in the Dry Zone of Sri Lanka due to temporal variability of rainfall. Sri Lanka's climate is divided into four rainfall seasons: First inter-monsoon (FIM) (March-April), Southwest monsoon (SWM) (MaySeptember), Second inter-monsoon (SIM) (October-November) and Northeast monsoon (NEM) (December-February). Maha, the major cultivation season falls from September to February, which overlaps with SIM and NEM. Yala, the minor cultivation season falls from March to August which is during FIM and SWM periods (Chithranayana and Punyawardena, 2014).

Climate variability brings adverse weather conditions such as droughts and floods (Trenberth, 2008), and high intensity rainfall. Accordingly, the rainfall variability can result in number of adverse impacts such as landslides (Melchiorre and Frattini, 2012, Rathnayake and Herath, 2005), destruction of infrastructure, agricultural lands and ecosystems (Smith, 2011, Vogel et al., 2019, Eriyagama et al., 2010). Several studies have revealed the climatic variability experienced during recent past in Sri Lanka (Wickramagamage, 2016, Jayawardena et al., 2018, Hemachandra et al., 2020).

Village tanks/ cascade systems have been constructed in Dry Zone of Sri Lanka to harvest rainwater. So that the collected water can be utilized for irrigation and other uses during dry periods (Madduma Bandara, 1985; Jayatilaka et al., 2003; Panabokke et al., 2001; Dharmasena, 2010). Therefore, small tanks/ cascade systems can be affected by climatic variability (Chandrasiri et al., 2020). Droughts affect the small tanks by depleting soil moisture, drying up vegetation (crops, natural fauna), increasing wild animal problems, etc. (Dharmasena, 2010). Heavy rains and floods also can damage the crops and the livelihood of people. Hence it is necessary to have an understanding of the pattern of rainfall variability for planning and management of farming under small tanks in order to minimize crop failures.

Standard Precipitation Index (SPI) can be identified as a widely applied methodology which only requires the precipitation data for investigating droughts and wet spells (McKee et al., 1993, Rawat and Tripathi, 2016, Abeysingha and Rajapaksha 2020, Herath et al., 2015, Khan et al., 2008, Li et al., 2008, Sönmez et al., 2005).

The objective of this study was to assess the variability of SPI and its trends from 1989 to 2018 in six rain gauging locations situated in an area dominated by small tanks and Tank Cascade Systems in North Central Dry Zone of Sri Lanka.

\section{METHODOLOGY}

\section{Description of data}

Daily rainfall data of thirty-year period (1989 2018) were collected from six rain gauging locations namely, Anuradhapura, Mahagalkadawala, Hingurakgoda, Maha Illuppallama, Girithale and Diyabeduma. These gauging stations are located in close proximity to numerous small village tanks and a number of important small tank cascade systems including Rathmale, Divulwewa, Athabendiwewa, Mahakanmulla, Thirappane, Ulagalla, Thoruwewa, Horivila- Palugaswewa and Ethabendiwewa in the North Central dry zone of Sri Lanka. Selection of the rain gauging stations was mostly influenced by the availability of data for the recent thirty year period and having only few missing rainfall data values. The rainfall data were collected from the Department of Meteorology, Natural Resources Management Centre of the Department of Agriculture and the Department of Irrigation, Sri Lanka. Figure 1 depicts the rain gauging locations and some important small tanks/ cascades present in the area.

\section{Analysis of Standard Precipitation Index}

The daily rainfall data were examined for missing rainfall values and other inconsistencies. The missing values of each station were filled with the values of the closest rain gauging station as it was considered as the most suitable option with the available data. The consistency of rainfall values at each station was assessed using mass curves and found to be consistent. It requires at least 30-year historical rainfall data to develop SPI (WMO, 2012). The SPI values can be interpreted as the number of standard deviations by which the observed value deviates from the long-term mean. Accordingly, the SPI is computed by dividing the difference between the normalized seasonal precipitation and its longterm seasonal mean by the standard deviation (Equation 1).

$S P I=(X i-X m) / \sigma$ .Eq: 1

where, $\mathrm{Xi}$ is $\mathrm{i}$ th observation of the seasonal precipitation at a particular rain gauge station, Xm the long-term seasonal mean of that particular rain gauge station and $\sigma$ is its standard deviation (Bhuiyan et al., 2006). The categorization of the moisture based on SPI value is presented in 


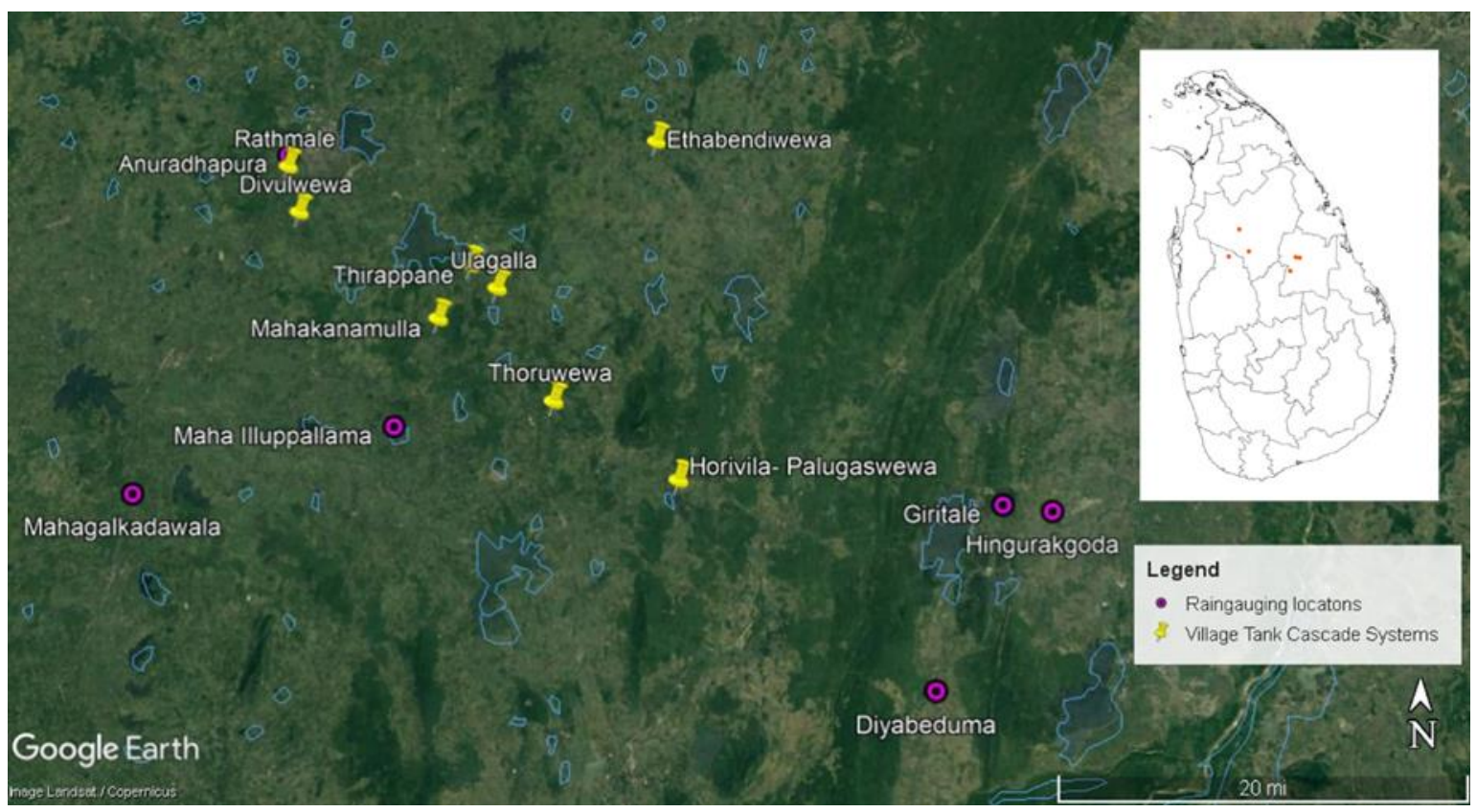

Figure 1: Locations of rain gauges considered in the study

Table 1. According to the classification of the index values, a level crossing at SPI $=+2 /-2$ indicates transition to extreme wetness/dryness, which corresponds to all values exceeding $5 \%$ confidence interval (Bordi et al., 2004).

Table 1: SPI categorization scheme

\begin{tabular}{ll}
\hline SPI value & Moisture Category \\
\hline$>2.00$ & Extreme wet \\
1.50 to 2.00 & Very wet \\
1.00 to 1.49 & Moderate wet \\
0.00 to 0.99 & Mild wet/Near normal \\
0.00 to -0.99 & Mild dry/ Near normal \\
-1.00 to -1.49 & Moderate drought \\
-1.50 to -1.99 & Severe drought \\
$<-2.00$ & Extreme drought \\
\hline
\end{tabular}

Source: McKee et al., 1993

In this study, SPI related to three-time scales; 3 month SPI (SPI 3), 6-month SPI (SPI 6) and 12month SPI (SPI 12) were developed.

SPI 12 was developed to assess the long-term precipitation patterns. Accordingly, SPI 12 for month of September (SPI 12 September) was taken for the analysis representing the annual rainfall variation of the hydrological years. "Water year/ Hydrological year" is defined as the 12-month period from October 1 for any given year through
September 30 of the following year (Dodge et al., 1998).

SPI 12 is a cumulative result of the shorter periods. Therefore, SPI 3 and SPI 6 were developed to assess the seasonal rainfall variations (main rainfall seasons and cultivation seasons).

SPI 3 for month of February (SPI 3 February) indicating the NEM, SPI 3 for month of May (SPI 3 May) indicating the FIM, SPI 3 for month of August (SPI 3 August) indicating SWM and SPI 3 for month of November (SPI 3 November) indicating SIM were developed.

According to WMO (2012) the 6-month SPI indicates seasonal to medium-term trends in precipitation and it is very effective in showing the precipitation over distinct seasons. Therefore, SPI 6 was developed to assess the droughts and wet extremes related to major cultivation seasons of Yala and Maha. Accordingly, SPI 6 was developed for months of February and August (SPI 6 February and SPI 6 August) to indicate the influences of the rainfall for two major cultivation seasons of Yala and Maha.

\section{Statistical methods for rainfall trend analysis}

A widely used non parametric trend analysis method of Mann Kendal Trend Test (MK test) and Sen's Slope estimator (Gocic and Trajkovic, 2013, 
Kumar et al., 2017) were used to assess the trends and magnitude of trends of developed SPI 3, 6 and 12 (Abeysingha and Rajapaksha., 2020; Li et al., 2008; Rahmat et al., 2012; Zhang et al., 2012) using "MAKESENS" application in Microsoft Excel (Rahman et al., 2016, Määttä et al., 2002, Sutapa, 2014, Sarkar and Ali, 2009). "MAKESENS" application can test the trend at significance levels of $0.001,0.01,0.05$ and 0.1 .

\section{Autocorrelation test}

Since the null hypothesis in the Mann-Kendall test is that the data are independent and randomly ordered, the existence of positive autocorrelation in the data increases the probability of detecting trends when actually non-exist, and vice versa (Hamed and Rao, 1998, Mondal et al., 2012, Yue and Wang 2004). Therefore, the serial autocorrelation was tested in the monthly rainfall data as well as the derived SPI 3,6 and 12 values to observe the presence of any serial dependency of rainfall data during 1989 to 2018 period prior to apply Mann Kendall test.

\section{Mann Kendal Trend Test (MK test)}

The null hypothesis $\left(\mathrm{H}_{0}\right)$ was identified as there is no trend in the data points in the record and the alternative hypothesis $\left(\mathrm{H}_{1}\right)$ was that there is an increasing or decreasing monotonic trend. Depending on the $\mathrm{Z}$ value, null hypothesis was accepted or rejected.

The MK test statistic $\mathrm{S}$ was calculated using Equation 2 and Equation 3 where $x_{j}$ and $x_{k}$ are the annual values in years $\mathrm{j}$ and $\mathrm{k}, \mathrm{j}>\mathrm{k}$, respectively.

$$
\begin{aligned}
& S=\sum_{k=1}^{n-1} \sum_{j=k+1}^{n} \operatorname{sgn}\left(x_{j}-x_{k}\right) \quad \text { Eq: } 2 \\
& \operatorname{sgn}\left(x_{j}-x_{k}\right)=\left\{\begin{array}{c}
1 \text { if } x_{j}-x_{k}>0 \\
0 \text { if } x_{j}-x_{k}=0 \\
-1 \text { if } x_{j}-x_{k}<0
\end{array} \quad \text { Eq: } 3\right.
\end{aligned}
$$

However, when $\mathrm{n} \geq 8$, the statistic $\mathrm{S}$ is approximately normally distributed with the mean (Mondal et al., 2012). Hence the variance statistic is given as in Equation 4.

$$
\begin{aligned}
& \operatorname{VAR}(S)=\frac{1}{18}\left[n(n-1)(2 n+5)-\sum_{p=1}^{q} t_{p}\left(t_{p}-\right.\right. \\
& \begin{array}{l}
\text { 1) } \left.\left(2 t_{p}+5\right)\right] \\
\text { Eq: } 4
\end{array}
\end{aligned}
$$

Here $q$ is the number of tied groups and tp is the number of data values in the $\mathrm{p}$ th group. The values of $\mathrm{S}$ and $\operatorname{VAR}(\mathrm{S})$ are used to compute the test statistic $\mathrm{Z}$ as Equation 5.
$Z=\left\{\begin{array}{l}\frac{S-1}{\sqrt{\operatorname{VAR}(S)}} \text { if } S>0 \\ 0 \text { if } S=0 \\ \frac{S+1}{\sqrt{\operatorname{VAR}(S)}} \text { if } S<0\end{array}\right.$

Eq: 5

Accordingly, $\mathrm{Z}$ test was used to assess the trend of SPI as this analysis provides 29 data points (from the hydrological year of $1989 / 1990$ to 2017/2018).

\section{Sen's Slope Estimator}

Sen's method is used to estimate the true slope of an existing trend (as change per unit time) where it is assumed to be linear (Equation 6).
$f(t)=Q t+B$
Eq: 6

where $\mathrm{Q}$ is the slope and B is a constant.

For obtaining Q, slopes of all the data value pairs were calculated. The estimation of slope of $\mathrm{N}$ pairs of data is expressed as Equation 7.

$Q_{i}=\frac{x_{j}-x_{k}}{j-k}$

Eq: 7

where, $\mathrm{J}>\mathrm{k}$ and $\mathrm{xj}$ and $\mathrm{xk}$ are data values at times $\mathrm{j}$ and $\mathrm{k}$ respectively. Hence, $\mathrm{Q}$ was estimated by the Sen's non-parametric method where the trend was assumed as linear using MAKESENS application. Hence, Sen's estimator for a linear trend calculated with the equation 8 by MAKESENS (Salmi et al., 2002).

$f($ year $)=Q \times($ year - first year $)+B \quad$ Eq: 8

\section{RESULTS AND DISCUSSION}

\section{Autocorrelation analysis}

According to the results of autocorrelation test, either the monthly rainfall data in individual locations or derived SPI 3, 6 and 12 are not autocorrelated. Therefore, the MK trend test and Sen's slope estimator was directly applied to assess the trend of SPI.

\section{Variability of SPI 12 September}

Figure 2 presents the occurrence of drought and wet events according to the derived "SPI 12 September" values during the period of 1989 to 2018. Accordingly, it indicates that 11 hydrological years of 1990 - 1991, 1991 - 1992, 1992 - 1993, 1995 - 1996, 1996 - 1997, 1998 - 1999, 2001 2002, 2003 - 2004, 2005 -2006, 2008 - 2009 and 




Figure 2: Number of rain gauging locations showing dry/ wet events in each hydrological year (1989 to 2018). Rain gauging locations: AR - Anuradhapura, DB - Diyabeduma, GT - Girithale, HG Hingurakgoda, MG - Mahagalkadawala, MI - Maha Illuppallama.

$2013-2014$ as drought years (SPI <=-1) while 10 hydrological years of 1993 - 1994, 1997-1998, 2000 - 2001, 2002 - 2003, 2006 - 2007, 20072008, 2010 - 2011, 2012-2013, 2014-2015 and 2015 - 2016 as wet years at least for one of the rain gauging location used in the study.

The SPI 12 looks at the annual rainfall variability considering the hydrological year. Table 2 presents the results of MK test and Sen's Slope Estimate for SPI 12 September.

Results indicate a significant increasing trend of annual rainfall in Anuradhapura,
Mahagalkadawala and Diyabeduma. There is no trend of annual rainfall in Maha Illuppallama, Girithale and Hingurakgoda.

MK test for Anuradhapura indicates an increasing trend of SPI 12 September at $\alpha=0.01$ level of significance. SPI 12 September increases by 0.06 towards "wet" per year in Anuradhapura. Accordingly, SPI 12 September for the future in there can be predicted by Equation 9. Abeysingha and Rajapaksha (2020) also have showed an increasing trend for SPI 12 for most of the locations in Dry Zone including Anuradhapura. 
Table 2: Results of Statistical analysis of SPI 12 September

\begin{tabular}{lcccc}
\hline \multirow{2}{*}{ Rain gauging location } & \multicolumn{2}{c}{ Mann-Kendall trend } & $\begin{array}{c}\text { Sen's slope } \\
\text { estimate }\end{array}$ & Intercept \\
\cline { 2 - 5 } & Test Z & Signific. & $\mathbf{Q}$ & B \\
\hline Anuradhapura & 2.72 & $* * *$ & 0.06 & -0.89 \\
Maha Illuppallama & 1.18 & & 0.02 & -0.34 \\
Mahagalkadawala & 1.74 & $*$ & 0.05 & -0.49 \\
Diyabeduma & 2.23 & $* *$ & 0.06 & -0.75 \\
Giritale & 1.33 & & 0.03 & -0.56 \\
Hingurakgoda & 0.43 & & 0.01 & -0.43 \\
\hline
\end{tabular}

*** , ** and $*$ indicates trends that are significant at $\alpha=0.01,0.05$ and 0.1 levels, respectively

SPI 12 sep in $n$th year in Anuradhapura $=$ $0.06 \times(n-1990)-0.8 \quad$ Eq: 9

Additionally, it indicates an increasing trend of SPI 12 September at $\alpha=0.1$ level of significance in Mahagalkadawala. Hence SPI 12 September increases by 0.05 towards "wet" per year in Mahagalkadawala. Accordingly, SPI 12 September for the future in there can be predicted by Equation 10.

SPI 12 sep in $n$th year in Mahagalkadawala $=$ $0.06 \times(n-1990)-0.49 \quad$ Eq:10

MK test for Diyabeduma indicates an increasing trend of SPI 12 September at $\alpha=0.05$ level of significance. Hence SPI 12 September increases by 0.06 towards wet per year in Diyabeduma. Accordingly, SPI 12 September for the future in there can be predicted by Equation 11.

SPI 12 sep in $n$th year in Diyabeduma $=$ $0.06 \times(n-1990)-0.75 \quad$ Eq: 11

The short term or the seasonal variabilities of rainfall can cause more impacts on the functioning of small tanks / tank cascade systems than the longterm variabilities such as SPI 12 and SPI 24. Therefore, SPI 3 and SPI 6 analyses present the short term and seasonal variabilities of rainfall.

\section{Variability of SPI 3 during 1989-2018 years}

SPI 3 provides a comparison of the precipitation over a specific 3-month period with the precipitation totals from the same 3-month period for all the years included in the historical record. Therefore, SPI 3 reflects short and medium-term moisture conditions and provides a seasonal estimation of precipitation. It is highly suitable for primary agricultural regions (WMO, 2012).

\section{SPI 3 February}

SPI 3 February in this analysis compares precipitation total of December, January and February in a particular year with the precipitation totals of the same period (December, January and February) in past thirty-years (1989 - 2018) in a particular location. Since the NEM rains also occur during December to February (Domroes and Ranatunge, 1992), SPI 3 February presents the changes of NEM rains.

According to MK test and Sen's Slope Estimate, none of the rain gauging locations showed significant trends in SPI 3 February. Hence it indicates that there is no significant trend in NEM rains for this area (Data are not presented).

\section{SPI 3 May}

SPI 3 May compares precipitation total of March, April and May in a particular year with the precipitation totals of the same period (March, April and May) in past thirty-years (1989 - 2018) in a particular location. Hence it includes the FIM which occurs during the months of March and April.

Table 3 shows that there is an increasing trend of rainfall at $\alpha=0.05$ level of significance in SPI 3 May at Anuradhapura and Maha Illuppinallama. Accordingly, SPI 3 May in Anuradhapura increases by 0.06 towards "wet" per year. SPI 3 May in Anuradhapura for the future can be predicted by Equation 12.

SPI 3 May in $n$th year in Anuradhapura $=$ $0.06 \times(n-1990)-0.77 \quad$ Eq: 12

Additionally, SPI 3 May in Maha Illuppallama increases by 0.05 towards wet per year. 
Accordingly, SPI 3 May in Maha Illuppallama for the future can be predicted by Equation 13 .

SPI 3 May in $n$th year in Maha Illuppallama = $0.05 \times(n-1990)-0.72 \quad$ Eq: 13

In fact, it shows that there is an increasing trend in the FIM rains in these areas. However, there is no trend of rainfall in Mahagalkadawala, Diyabeduma, Giritale and Higurakgoda during FIM.

Since dry zone of Sri Lanka is receiving highly intensive rains during inter monsoonal periods (Abeysekera et al., 2015), the increments of SPI 3 could be due to increase of high intensive rains.

\section{SPI 3 August}

SPI 3 August compares the precipitation total of June, July and August in a particular year with precipitation totals of the same period (June, July and August) in past thirty-years (1989-2018) in a particular location. It represents the SWM season.
However, according to, MK test and Sen's Slope Estimate, there was no trend of SPI 3 August in all the rain gauging locations (Data are not presented).

\section{SPI 3 November}

SPI 3 November in this analysis compares precipitation totals of September, October and November in a particular year with the precipitation totals of the same period (September, October and November) in past thirty-years (1989 - 2018) of a particular location. Hence it represents the SIM period of October and November.

Table 4 shows that SPI 3 November in Anuradhapura increases by 0.05 towards "wet" per year. Accordingly, SPI 3 November in Anuradhapura for the future can be predicted by Equation 14.

SPI 3 Nov in $n$th year in Anuradhapura $=$ $0.05 \times(n-1990)-0.65$

Eq:14

Table 3: Results of statistical analysis of SPI 3 May

\begin{tabular}{lcccc}
\hline \multirow{2}{*}{ Rain gauging location } & \multicolumn{2}{c}{ Mann-Kendall trend } & Sen's slope estimate & \multicolumn{2}{c}{ Interceptor } \\
\cline { 2 - 5 } & Test Z & Signific. & $\mathrm{Q}$ & $\mathrm{B}$ \\
\hline Anuradhapura & 2.53 & $* *$ & 0.06 & -0.77 \\
Maha Illuppallama & 2.01 & $* *$ & 0.05 & -0.72 \\
Mahagalkadawala & 1.48 & & 0.02 & -0.07 \\
Diyabeduma & 1.59 & & 0.03 & -0.42 \\
Giritale & 0.28 & 0.01 & -0.23 \\
Hingurakgoda & -0.13 & 0.00 & 0.02 \\
\hline
\end{tabular}

$* * *, * *$ and $*$ indicates trends that are significant at $\alpha=0.01,0.05$ and 0.1 levels, respectively

Table 4: Results of statistical analysis of SPI 3 November

\begin{tabular}{lcccc}
\hline \multirow{2}{*}{ Rain gauging location } & \multicolumn{2}{c}{ Mann-Kendall trend } & Sen's slope estimate & \multicolumn{2}{c}{ Interceptor } \\
\cline { 2 - 5 } & Test Z & Signific. & $\mathbf{Q}$ & $\mathbf{B}$ \\
\hline Anuradhapura & 1.82 & $*$ & 0.05 & -0.65 \\
Maha Illuppallama & -0.43 & & -0.01 & 0.26 \\
Mahagalkadawala & 0.73 & & 0.02 & -0.13 \\
Diyabeduma & 1.22 & & 0.03 & -0.49 \\
Giritale & 0.13 & 0.00 & -0.22 \\
Hingurakgoda & -0.51 & -0.01 & 0.12 \\
\hline
\end{tabular}

$* * *,{ }^{* *}$ and ${ }^{*}$ indicates trends that are significant at $\alpha=0.01,0.05$ and 0.1 levels, respectively

In fact, the trend of SPI 3 can be neglegible in relation to four rainfall seasons during 1989- 2018 in the study area. Perera et al., 2016 also have revealed that there was no significant variability in 
four rainfall seasons in Maha Illupalama during 1991 to 2010.

\section{Variability of SPI 6 February and August}

SPI 6 provides a comparison of the precipitation over a specific 6-month period with the precipitation totals from the same 6-month period for all the years included in the historical record. SPI 6 February compares the precipitation total for the September to February period in a particular year with precipitations for that same period (September to February) in past thirty-years (1989 - 2018) in a particular location. Hence it indicates the variabilities of the effective rainfall for the Maha season (September to February). Generally, in Maha season this area receives high amount of rainfall and people expect the village tanks to be filled during the period. Hence, they can use the water for irrigation during Maha season and store the extra water for cultivation in Yala season. However, if a drought occurres during Maha season, the farmers who cultivate using village tanks have to face a risk due to lack of water for the cultivations in both seasons. However, MK test showed that none of the rain gauging locations have shown a significant trend in SPI 6 February (Data are not presented).

SPI 6 August compares the precipitation totals of March to August period of a particular year with precipitations for that same period (March to August) in past thirty-years (1989 - 2018) in a particular location. Hence it indicates the rainfall variability of Yala season (March to August).

According to Table 5, Anuradhapura and Maha Illuppallama show significant increasing trends of rainfall in Yala season. MK test for Anuradhapura indicates an increasing trend of SPI 6 August at $\alpha=$ 0.05 level of significance. Accordingly, SPI 6 August in Anuradhapura increases by 0.05 towards wet per year. SPI 6 August in Anuradhapura for the future can be predicted by Equation 17.

SPI 6 Aug in $n$th year in Anuradhapura $=$
$0.05 \times(n-1990)-0.84 \quad$ Eq: 15

Additionally, MK test for Maha Illuppallama indicates an increasing trend of SPI 6 August at $\alpha=$ 0.1 level of significance. Accordingly, SPI 6 August in Maha Illuppallama increases by 0.05 towards wet per year. SPI 6 August in Maha Illuppallama for the future can be predicted by Equation 16.

SPI 6 Aug in $n$th year in Maha Illuppallama = $0.05 \times(n-1990)-0.69 \quad$ Eq:16

Even though most of the rain gauging locations show random increasing trends of seasonal or annual rainfalls (SPI3/ SPI 6/ SPI 12) a continuous increasing or decreasing trend was not observed except in Anuradhapura. Hence it is obvious that the increasing trends of SPI at different locations at different time periods were due to extreme rainfall events. Abeysekera et al. (2015) also revealed about an increasing trend of extreme rainfall events during 1990 - 2014 period in dry zone of Sri Lanka

Hence the untimely rainfall can adversely affect to the sustainability of village tanks / cascade systems interrupting human activities, crop production, hydrologic relations including eco system functions. Since small village tanks play a vital role in livelihood of the people in this area, it is important to consider sustainable management of these tanks and cascade systems to cope up with the changing climatic conditions. Hence it is understood that future studies should be focused on shifting of the rainfall seasons and defining the cultivation seasons accordingly as an adaptation strategy.

Table 5 Results of Statistical analysis of SPI 6 August

\begin{tabular}{|c|c|c|c|c|}
\hline \multirow[b]{2}{*}{ Rain gauging location } & \multicolumn{2}{|c|}{ Mann-Kendall trend } & \multirow{2}{*}{$\begin{array}{l}\text { Sen's slope estimate } \\
\mathrm{Q}\end{array}$} & \multirow{2}{*}{$\begin{array}{l}\text { Interceptor } \\
\mathrm{B}\end{array}$} \\
\hline & Test Z & Signific. & & \\
\hline Anuradhapura & 2.31 & $* *$ & 0.05 & -0.84 \\
\hline Maha Illuppallama & 1.86 & $*$ & 0.05 & -0.69 \\
\hline Mahagalkadawala & 1.48 & & 0.02 & -0.21 \\
\hline Diyabeduma & 1.63 & & 0.03 & -0.38 \\
\hline Giritale & 0.28 & & 0.00 & 0.17 \\
\hline Hingurakgoda & -0.62 & & -0.02 & 0.33 \\
\hline
\end{tabular}

$* * *, * *$ and $*$ indicates trends that are significant at $\alpha=0.01,0.05$ and 0.1 levels, respectively 


\section{CONCLUSIONS}

The variability of rainfall is evident in this area according to the SPI analysis which shows alternative dry and wet periods. Rain gauging locations of Anuradhapura, Diyabeduma and Mahagalkadawala shows an increasing trend of annual rainfall. In seasonal rainfall, there are no trends in the main two monsoons (either NEM or SWM) in any of the rain gauging location. However, increasing trends were observed in FIM in Anuradhapura and Maha Illuppalama which had resulted in an increasing rainfall trend in Yala season. Therefore, it can be considered as a positive impact for agriculture since water scarcity is a major obstacle for farming in Yala

\section{REFERENCES}

Abeysekera, A.B., Punyawardena, B.V.R. and Premalal, K.H.M.S. (2015). Recent trends of extreme positive rainfall anomalies in the dry zone of Sri Lanka. Annals of the Sri Lanka Department of Agriculture, 17, 1-4.

Abeysingha, N.S. and Rajapaksha, U.R.L.N. (2020). SPI-Based Spatiotemporal Drought over Sri Lanka. Advances in Meteorology, 2020.

Ahmad, L., Parvaze, S., Majid, M. and Kanth, R.H. (2016). Analysis of historical rainfall data for drought investigation using standard precipitation index (SPI) under temperate conditions of Srinagar Kashmir. Pakistan Journal of Meteorology, 13(25).

Bhuiyan, C., Singh, R.P. and Kogan, F.N. (2006). Monitoring drought dynamics in the Aravalli region (India) using different indices based on ground and remote sensing data. International Journal of Applied Earth Observation and Geoinformation, 8(4), 289-302.

Bordi, I., Fraedrich, K., Jiang, J.M. and Sutera, A. (2004). Spatio-temporal variability of dry and wet periods in eastern China. Theoretical and Applied Climatology, 79(1-2), 81-91.

Chandrasiri, S., Galagedara, L. and Mowjood, M. (2020). Impacts of rainfall variability on paddy production: A case from Bayawa minor irrigation tank in Sri Lanka. Paddy and Water Environment, 1-12.

Chithranayana, R.D. and Punyawardena, B.V.R. (2014). Adaptation to the vulnerability of paddy cultivation to climate change based on seasonal season. Additionally there was an increasing trend of SIM in Anuradhapura. There were no trends of SPI 3 and SPI 6 Hingurakgoda, Diyabeduma and Mahagalkadawala and there may be random extreme rainfall events which have made the increasing trend only for the annual rainfall. Hence it can be concluded that there can be an increment of random extreme heavy rainfalls in this area in the future.

\section{ACKNOWLEDGEMENT}

This work was carried out with the aid of a grant from the International Development Research Center (IDRC), Ottawa, Canada. Their financial support is greatly appreciated.

rainfall characteristics. Journal of the National Science Foundation of Sri Lanka, 42(2).

Dharmasena, P.B. (2010). Essential components of traditional village tank systems. In Proceedings of the national conference on cascade irrigation systems for rural sustainability, Central Environmental Authority, Sri Lanka (Vol. 9).

Dodge, K.A., Hornberger, M.I. and Axtmann, E.V. (1998). Water-quality, bed-sediment, and biological data (October 1995 through September 1996) and statistical summaries of data for streams in the upper Clark Fork basin, Montana. US Department of the Interior, US Geological Survey.

Domroes, M. and Ranatunge, E. (1992). The orthogonal structure of Monsoon rainfall variation over Sri Lanka. Theoretical and Applied Climatology, 46(2-3), 109-114.

Eriyagama, N., Smakhtin, V., Chandrapala, L. and Fernando, K. (2010). Impacts of climate change on water resources and agriculture in Sri Lanka: A review and preliminary vulnerability mapping (Vol. 135). IWMI.

Gocic, M. and Trajkovic, S. (2013). Analysis of changes in meteorological variables using Mann-Kendall and Sen's slope estimator statistical tests in Serbia. Global and Planetary Change, 100, 172-182.

Hamed, K.H. and Rao, A.R. (1998). A modified Mann-Kendall trend test for autocorrelated data. Journal of Hydrology, 204(1-4), 182-196.

Hemachandra, E.M.G.P., Dayawansa, N.D.K. and De Silva, R.P. (2020). Developing a composite map 
of vulnerability to rainfall extremes in sri lanka. pp. 63-84. In Haque, A. and Chowdhury, A. I. A. Eds. Water, Flood Management and Water Security Under a Changing Climate. Springer International Publishing.

Herath, H.M.R.C., Premalal, K.H.M.S., Kaumudie, A.L.I. and Sanjeewani, D.M.N. (2015). Analysis of Standard Precipitation Indices to Identify for Drought Condition in 2015. Sri Lanka Journal of Meteorology, Colombo, 1, 20-31.

Khan, S., Gabriel, H.F. and Rana, T. (2008). Standard precipitation index to track drought and assess impact of rainfall on water tables in irrigation areas. Irrigation and Drainage Systems, 22(2), 159-177.

Kumar, N., Panchal, C.C., Chandrawanshi, S.K. and Thanki, J.D. (2017). Analysis of rainfall by using Mann-Kendall trend, Sen's slope and variability at five districts of south Gujarat, India. Mausam, 68(2), 205-222.

Li, W., Fu, R., Juarez, R.I.N. and Fernandes, K. (2008). Observed change of the standardized precipitation index, its potential cause and implications to future climate change in the Amazon region. Philosophical Transactions of the Royal Society B: Biological Sciences, 363(1498), 1767-1772.

Määttä, A., Salmi, T., Anttila, P. and Ruoho-Airola, T. (2002). MAKESENS 1.0. EXCEL template for the calculation of trend statistics of annual time series. Finnish Meteorological Institute, Helsinki.

Madduma Bandara C.M. (1985) Catchment Ecosystems and Village Tank Cascades in the Dry Zone of Sri Lanka A Time-Tested System of Land and Water Resource Management. pp. 99113. In: Lundqvist J., Lohm U., Falkenmark M. (Eds.) Strategies for River Basin Management. The GeoJournal Library, vol 6. Springer, Dordrecht. https://doi.org/10.1007/978-94009-5458-8_11.

McKee, T.B., Doesken, N.J. and Kleist, J. (1993, January). The relationship of drought frequency and duration to time scales. In Proceedings of the 8th Conference on Applied Climatology, $17(22), 179-183$.

Melchiorre, C. and Frattini, P. (2012). Modelling probability of rainfall-induced shallow landslides in a changing climate, Otta, Central Norway. Climatic Change, 113(2), 413-436.
Ministry of agriculture and FAO, (2017). A proposal for declaration as a giahs the cascaded tankvillage system (ctvs) in the dry zone of Sri Lanka.

Mondal, A., Kundu, S. and Mukhopadhyay, A., 2012. Rainfall trend analysis by Mann-Kendall test: A case study of north-eastern part of Cuttack district, Orissa. International Journal of Geology, Earth and Environmental Sciences, 2(1), 70-78.

Panabokke, C.R., Tennakoon, M.U.A. and Ariyabandu, R.D.S. (2001). Small tank systems in Sri Lanka: issues and considerations. In Proceedings of the workshop on food security and small tank systems in Sri Lanka. National Science Foundation, Colombo, Sri Lanka (pp. 16).

Perera, A.C.S., Punyawardena, B.V.R. and Gunawardena, E.R.N. (2016). Recent changes of rainfall Regime of Hakwatuna Oya watershed of Sri Lanka. Tropical Agricultural Research, 28(1), 50.

Rahman, A.S., Kamruzzama, M., Jahan, C.S. and Mazumder, Q.H. (2016). Long-term trend analysis of water table using 'MAKESENS' model and sustainability of groundwater resources in drought prone Barind area, NW Bangladesh. Journal of the Geological Society of India, 87(2), 179-193.

Rahmat, S.N., Jayasuriya, N. and Bhuiyan, M. (2012). Trend analysis of drought using standardised precipitation index (SPI) in Victoria, Australia. In Hydrology and Water Resources Symposium 2012 (p. 441). Engineers Australia.

Rawat, K.S., and Tripathi, V.K. (2016). Standardized precipitation index based approach for development of regional drought monitoring system. Journal of Remote Sensing Technology, 4, 48-57.

Salmi, T., Määttä, A., Anttila, P., Ruoho-Airola, T. and Amnell, T. (2002). Detecting trends of annual values of atmospheric pollutants by the MannKendall test and Sen's slope estimates MAKESENS-The excel template application. Finish Meteorological Institute, Helsinki.

Sarkar, A.A. and Ali, M. H. (2009). Water table dynamics of Dhaka City and its long-term trend analysis using the "MAKESENS" model. Water International, 34(3), 373-382. 
Smith, M.D. (2011). An ecological perspective on extreme climatic events: a synthetic definition and framework to guide future research. Journal of Ecology, 99(3), 656-663.

Sönmez, F.K., Koemuescue, A.U., Erkan, A. and Turgu, E. (2005). An analysis of spatial and temporal dimension of drought vulnerability in Turkey using the standardized precipitation index. Natural Hazards, 35(2), 243-264.

Sutapa, I.W. (2014). Application model MannKendall and Sen's (Makesens) for detecting climate change. Infrast. J. Civil Eng. Univ. Tadulako, 4, 31-40.

Trenberth, K.E. (2008). The Impact of Climate Change and Variability on Heavy Precipitation, Floods, and Droughts. In M. G. Anderson and J. J. McDonnell (Eds.), Encyclopedia of Hydrological Sciences (p. hsa211). John Wiley and Sons, Ltd.

Vogel, E., Donat, M.G., Alexander, L.V., Meinshausen, M., Ray, D.K., Karoly, D., Meinshausen, N. and
Frieler, K., (2019). The effects of climate extremes on global agricultural yields. Environmental Research Letters, 14(5), 054010 .

Wickramagamage, P. (2016). Spatial and temporal variation of rainfall trends of Sri Lanka. Theoretical and Applied Climatology, 125(3-4), 427-438.

WMO (World Meteorological Organization), (2012). Standardized precipitation index user guide. World Meteorological Organization, (1090).

Yue, S. and Wang, C. (2004). The Mann-Kendall test modified by effective sample size to detect trend in serially correlated hydrological series. Water resources management, 18(3), 201-218.

Zhang, Q., Li, J., Singh, V. P. and Bai, Y. (2012). SPIbased evaluation of drought events in Xinjiang, China. Natural Hazards, 64(1), 481-492. 